\title{
INDUKSI 2-METHOXYETHANOL PADA MASA PRENATAL SEBAGAI PENYEBAB KELAINAN OTAK PADA MENCIT
}

\author{
Win Darmanto, Eko Prihiyantoro, Ria Harmonis \\ Jurusan Biologi Fakultas MIPA Universitas Airlangga
}

\begin{abstract}
2-Methoxyethanol (2-ME) and glycol esters are widely used as a solvents in the industry and plasticizers, and have becomes ubiquitous environmental pollutants. This study were designed to evaluate the malformation of brain development as an impact of 2-ME. Four groups of pregnant mice were injected to 2-ME dose $10 \mathrm{mmol} / \mathrm{kg}$ body weight at 7, 13, 15, and 17 days gestation respectively. Control group were injected with sterile water. At 18 days of gestation samples in groups 7 and 13 days gestation were sacrificed. Brain were remove and weight, morfologically and histologically were examined. Samples were divided into five groups, i.e. control group, $7^{\text {th }}, 13^{\text {rd }}, 15^{\text {th }}$ and $17^{\text {th }}$ days of gestation groups. Samples in $7^{\text {th }}$ and $15^{\text {th }}$ days of gestation groups killed in $18^{\text {th }}$ days of gestation to observed fetal brain defect and decreased of fetal brain weight but some samples to allow delivery of fetuses. Furthermore, the fetuses killed on 0, 5, 10, and 20 days after birth, to take their brain. The result of these study showed that there are decreasing total weight of fetal brains and there are cerebral malformation as impact of 2-ME exposure.
\end{abstract}

Key words: cerebrum, cerebellum, mice, 2-methoxyethanol

\section{PENGANTAR}

Pada dasawarsa terakhir ini, telah dilaporkan adanya dampak negatif dari bahan-bahan kimia pencemar lingkungan, di antaranya menyebabkan gangguan pada sistem saraf pusat, efek teratogenik maupun embriotoksik baik pada hewan maupun manusia (Colborn et al., 1993 dan Hutchison, 1997). Senyawa 2-Methoxyethanol (2-ME) tergolong senyawa phthalate ester (ester ftalat) yang merupakan salah satu bahan dasar plastik (plasticizer) dan bahan pelarut dalam industri cat. Senyawa tersebut diketahui bersifat toksik baik pada individu dewasa maupun pada embrio yaitu embriotoksik dan teratogenik (penyebab cacat kandungan) pada beberapa spesies mamalia (Feuston et al., 1990, Darmanto et al., 1998). Sifat embriotoksik dan teratogenik 2-ME pada hewan percobaan juga telah dipelajari baik secara in vivo maupun in vitro (Darmanto et al., 1994a; Darmanto et al., 1994b; Darmanto et al., 1994c; Yonemoto and Brown, 1984), efek tersebut diduga disebabkan oleh hasil metabolisme 2-ME di dalam sel liver menjadi methoxyacetic acid (MAA), dengan bantuan katalisator alcohol dehydrogenase (ADH) (Brown et al., 1984, Moslen et al., 1995). Senyawa 2-ME juga diketahui sangat potensial menyebabkan kelainan perkembangan otak yaitu menyebabkan otak terdedah (excencephaly) (Ketti et al., 1996; Darmanto et al., 1994a; Darmanto et al., 1998).

Penelitian ini bertujuan untuk mengetahui adanya kelainan otak pada fetus yang induknya terdedah oleh bahan teratogenik 2-ME pada masa kebuntingan tertentu sesuai dengan masa kritis perkembangan otak. Pengamatan dilakukan pada masa prenatal maupun postnatal, meliputi kelainan morfologi maupun kelainan histologi pada cerebelum dan cerebrum.

\section{BAHAN DAN CARA KERJA}

Hewan yang digunakan dalam penelitian ini adalah mencit (Mus musculus) betina dari strain BALB/C yang berumur delapan minggu, diperoleh dari Pusat Veteriner Farma (PUSVETMA) Surabaya. Sebelum dikawinkan dilakukan superovulasi dengan menggunakan PMSG dan HCG dengan konsentrasi 5 IU dengan volume pemberiannya $0,1 \mathrm{ml}$. Selanjutnya mencit betina bunting diberi perlakuan dengan cara menyuntikkan larutan 2-ME dengan dosis pemberian $10 \mathrm{mmol} / \mathrm{kg}$ BB dengan volume penyuntikan $0,1 \mathrm{ml} / 10 \mathrm{~g}$ berat badan. Kelompok kontrol disuntik dengan aquabides steril. Penelitian ini meliputi lima kelompok perlakuan yaitu kelompok kontrol, kelompok perlakuan umur kehamilan 7 (UK 7), UK 13, UK 15 dan kelompok perlakuan UK 17. Pada kelompok perlakuan UK 7 dan UK 13 induk mencit dibedah pada umur kebuntingan 18 hari, kemudian diamati kelainan otak yang terjadi dengan cara pengamatan secara morfologi dan histologi yaitu dengan menggunakan sayatan otak dengan metode parafin, serta dilakukan penimbangan berat otak. Kelompok perlakuan UK 15 dan UK 17 hari induk mencit dibiarkan untuk melahirkan anaknya. Pengambilan otak mencit dilakukan pada saat mencit berumur 0 hari (saat lahir), 5 , 10, dan 20 hari. Selanjutnya dilakukan pengamatan secara histologis dengan menggunakan pewarnaan HE. 
HASIL

\section{Kelainan Perkembangan Otak Fetus Mencit akibat Pemberian 2-ME}

Pengamatan terhadap efek 2-ME terhadap perkembangan otak, baik berupa penurunan berat otak dan kelainan pada otak dapat dilihat pada Tabel 1. Pengamatan terhadap berat otak yang diambil dari fetus hidup, menunjukkan adanya penurunan secara nyata pada kelompok perlakuan UK 7 dan UK 13 hari.

Ada kecenderungan penurunan berat otak ini disebabkan oleh adanya penurunan perkembangan fetus secara keseluruhan, seperti yang dapat dilihat pada penurunan berat badan fetus. Kelainan perkembangan otak, khususnya pada cerebrum yaitu berupa penipisan korteks cerebrum dan pelebaran ventrikel lateral pada cerebrum. Penipisan korteks cerebrum terutama terjadi pada kelompok perlakuan UK 13, hal ini sesuai dengan masa perkembangan cerebrum terjadi sangat pesat sekitar UK 13 hari, begitu juga pada insidensi pelebaran ventrikel lateral banyak terjadi pada kelompok perlakuan UK 13 hari.

\section{Perkembangan Fetus Pascalahir (anak mencit) Akibat Induksi 2-ME}

Pengamatan terhadap perkembangan anak mencit pascalahir pada penelitian ini terutama dilakukan pada kelompok perlakuan UK 15 dan 17 hari. Hal ini karena pada UK 15 hari adalah masa awal terbentuknya cerebellum dan mulai kelihatan berkembangnya pada UK 17 hari. Pada minggu pertama setelah kelahiran, cerebellum berkembang sangat pesat, oleh karena itu pengamatan terhadap cerebellum difokuskan pada masa pascalahir, khususnya untuk kelainan perkembangan cerebellum.

Kondisi perkembangan anak mencit secara keseluruhan akibat induksi 2-ME pada masa pembentukan cerebellum dapat dilihat di Tabel 2.

Pengamatan terhadap jumlah anak mencit hidup dilakukan pada saat lahir sampai berumur 20 hari. Induksi 2-ME pada induk mencit umur kebuntingan 15 dan 17 hari yaitu masa awal pembentukan cerebellum menyebabkan penurunan daya tahan hidup anak mencit bila dibandingkan dengan kontrol, yang ditandai dengan banyaknya anak mencit yang mati sebelum berumur 20 hari. Dari Tabel 2 dapat dilihat bahwa, kemampuan hidup anak mencit kelompok perlakuan lebih rendah, bila dibandingkan dengan kemampuan hidup anak mencit kelompok kontrol. Jumlah anak mencit yang mati sebelum berumur 20 hari banyak terjadi pada mencit perlakuan, baik pada kelompok mencit perlakuan UK 15 maupun UK 17 hari, khususnya pada kelompok UK 17. Hal ini menandakan 2-ME mempengaruhi kondisi fetus mulai dari masa perkembangan embrio pralahir sampai anak mencit pascalahir.

Tabel 1. Kondisi perkembangan embrio dan insiden kelainan perkembangan cerebrum berupa penipisan korteks cerebrum dan pelebaran ventrikel dari fetus mencit setelah induknya diinjeksi 2-ME

\begin{tabular}{|c|c|c|c|c|c|c|c|}
\hline \multirow[b]{2}{*}{$\begin{array}{l}\text { Perlakuan } \\
\text { (hari) }\end{array}$} & \multirow[b]{2}{*}{$\begin{array}{l}\text { Dosis 2- } \\
\text { ME (mmol/ } \\
\text { kg BB) }\end{array}$} & \multirow[b]{2}{*}{$\begin{array}{c}\text { Berat fetus } \\
\text { (gram) }\end{array}$} & \multirow[b]{2}{*}{ • Induk } & \multirow[b]{2}{*}{$\begin{array}{l}\text { Jumlah fetus } \\
\text { yang diamati }\end{array}$} & \multirow[b]{2}{*}{$\begin{array}{c}\text { Berat otak fetus } \\
\text { (gram) }\end{array}$} & \multicolumn{2}{|c|}{ \% Insiden Kelainan Otak (n) } \\
\hline & & & & & & $\begin{array}{c}\text { Korteks } \\
\text { Cerebrum } \\
\text { menipis }\end{array}$ & $\begin{array}{c}\text { Ventrikel } \\
\text { lateral } \\
\text { melebar }\end{array}$ \\
\hline- & $\begin{array}{c}\text { Kontrol } \\
(0)\end{array}$ & 1,23 & 5 & 26 & 0,062 & 0 & 0 \\
\hline Uk 7 & 10 & $0,98^{*}$ & 5 & 6 & 0,049 * & $25^{\star}$ & 35 * \\
\hline Uk 13 & 10 & $0,95^{\star}$ & 5 & 18 & 0,047 * & 84 * & 52 * \\
\hline
\end{tabular}

Tabel 2. Kondisi daya tahan hidup anak mencit dari saat lahir sampai umur 20 hari setelah induknya diberi 2-ME

\begin{tabular}{ccccc}
\hline Perlakuan (hari) & $\begin{array}{c}\text { Dosis 2-ME } \\
\text { (mmol/kg BB) }\end{array}$ & $\bullet$ Induk & $\begin{array}{c}\bullet \text { Anak Mencit } \\
\text { Hidup Saat Lahir }\end{array}$ & $\begin{array}{c}\text { \% Anak Mencit yang Mampu } \\
\text { Hidup Hingga umur 20 Hari }\end{array}$ \\
\hline Kontrol & 0 & 5 & 34 & 100 \\
UK 15 & 10 & 5 & 41 & 64 * \\
UK 17 & 10 & 5 & 31 & 26 * \\
\hline
\end{tabular}

UK $=$ umur kebuntingan $\quad$ * $=$ signifikan pada $\alpha \leq 0,05$ (Mann-Whitney $U$ test) 


\section{Pengamatan terhadap Perkembangan Cerebrum Pascalahir}

Pengamatan terhadap cerebrum berupa kelainan pada bagian korteks cerebrum yang teramati pada anak mencit umur 0 hari (saat lahir), umur 5, 10, dan 20 hari terlihat pada Tabel 3.

Pada Tabel 3, menunjukkan bahwa pemeriksaan otak anak mencit umur nol hari dan lima hari belum tampak adanya kelainan histologis dari korteks cerebrum, namun pada anak mencit umur 10 dan 20 hari, tampak adanya kelainan yang muncul pada korteks cerebrum. Hal ini diduga 2-ME dapat menyebabkan kerusakan jaringan korteks. Pada masa minggu pertama setelah kelahiran kerusakan itu belum tampak jelas, namun seiring dengan perkembangan cerebrum, terjadi proses pemulihan dari kerusakan jaringan korteks. Namun proses pemulihan tersebut tampak tidak sempurna, sehingga memperlihatkan adanya penyimpangan perkembangan yang dapat dilihat pada anak mencit umur 10 dan 20 hari. Kelainan otak lainnya yang muncul adalah perkembangan hipocampus asimetris (data tidak ditampilkan).

Tabel 3. Persentase kelainan cerebrum korteks anak mencit pada umur $0,5,10$, dan 20 hari yang induknya diberi 2-ME pada umur kebuntingan 15 dan 17 hari

\begin{tabular}{llcc}
\hline $\begin{array}{c}\text { Umur } \\
\text { pengamatan } \\
\text { anak mencit }\end{array}$ & $\begin{array}{l}\text { Kelompok } \\
\text { perlakuan }\end{array}$ & $\begin{array}{c}\text { Perlakuan } \\
\text { pada umur } \\
\text { kebuntingan }\end{array}$ & $\begin{array}{c}\text { \% Kerusakan } \\
\text { Korteks } \\
\text { Cerebrum (n) }\end{array}$ \\
\hline $\begin{array}{l}\text { Saat lahir } \\
\text { (nol hari) }\end{array}$ & Kontrol & & $0(4)$ \\
\cline { 2 - 4 } & Perlakuan & 15 & $0(6)$ \\
\hline 5 hari & Kontrol & 17 & $0(5)$ \\
\cline { 2 - 4 } & Perlakuan & 15 & $0(4)$ \\
\hline 10 hari & Kontrol & 17 & $0(4)$ \\
& Perlakuan & 15 & $0(4)$ \\
\hline 20 hari & Kontrol & 17 & $0(4)$ \\
\cline { 2 - 4 } & Perlakuan & 15 & $100(3){ }^{*}$ \\
\hline & & 17 & $0(3)$ \\
\hline
\end{tabular}

UK = umur kebuntingan

* = signifikan pada $\alpha \leq 0,05$ (Mann-Whitney $\mathrm{U}$ test)

\section{Kelainan Perkembangan pada Otak Bagian Cerebellum}

Cerebellum merupakan bagian otak yang berfungsi sebagai koordinasi keseimbangan dan mulai terbentuk pada UK 15 hari dan terus berkembang sampai anak mencit berumur 20 hari. Pengamatan perkembangan cerebellum akibat induksi 2-ME pada UK 15 dan 17 hari yang diamati pada anak mencit umur 0 hari, 5, 10, dan 20 hari terlihat pada Tabel 4. Jenis kelainan yang terjadi pada cerebellum yang tampak pada penelitian ini adalah kelainan foliasi (Gambar 1). Dari hasil sayatan bidang mid saggital terhadap cerebellum tampak adanya perubahan pola foliasi bila dibandingkan dengan cerebellum anak mencit kontrol. Persentase penyimpangan pola folisasi tersebut mulai terlihat pada anak mencit umur 0 hari sampai umur 20 hari. Persentase penyimpangan tersebut lebih tinggi terjadi pada kelompok perlakuan UK 17 hari. Hal ini sudah sesuai dengan masa kritis pembentukan pola foliasi yaitu terjadi pada masa akhir kebuntingan sampai anak mencit umur 4 hari (Darmanto et al., 2000).
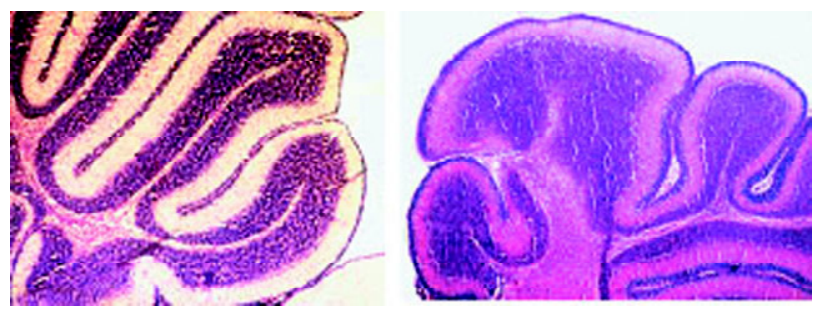

Gambar 1. Sayatan histologi cerebellum anak mencit umur 10 hari. A: kontrol; B: diinduksi 2-ME pada uk 15 hari dosis $10 \mathrm{mmol} / \mathrm{kg} \mathrm{BB}$, tampak adanya kelainan pola foliasi (40 $\times \mathrm{HE})$.

Tabel 4. Persentase kelainan pola foliasi pada cerebellum anak mencit pada umur $0,5,10$, dan 20 hari yang induknya diberi 2-ME pada umur kebuntingan 15 dan 17 hari

\begin{tabular}{|c|c|c|c|}
\hline $\begin{array}{c}\text { Umur } \\
\text { pengamatan } \\
\text { anak mencit }\end{array}$ & $\begin{array}{l}\text { Kelompok } \\
\text { perlakuan }\end{array}$ & $\begin{array}{c}\text { Umur } \\
\text { Kebuntingan }\end{array}$ & $\begin{array}{c}\% \text { insiden } \\
\text { kelainan pola } \\
\text { foliasi }(\mathrm{n})\end{array}$ \\
\hline \multirow{3}{*}{$\begin{array}{l}\text { Saat lahir } \\
\text { (nol hari) }\end{array}$} & Kontrol & - & $0(3)$ \\
\hline & \multirow{2}{*}{$\begin{array}{l}\text { Perlakuan } \\
\text { 2-ME }\end{array}$} & 15 & $100(3)$ * \\
\hline & & 17 & $100(6)$ * \\
\hline \multirow{3}{*}{ Lima hari } & Kontrol & - & $0(1)$ \\
\hline & \multirow{2}{*}{$\begin{array}{l}\text { Perlakuan } \\
\text { 2-ME }\end{array}$} & 15 & $50(4)$ \\
\hline & & 17 & $100(4)^{*}$ \\
\hline \multirow{3}{*}{ Sepuluh hari } & Kontrol & - & $0(5)$ \\
\hline & \multirow{2}{*}{$\begin{array}{l}\text { Perlakuan } \\
\text { 2-ME }\end{array}$} & 15 & $60(5)$ * \\
\hline & & 17 & $100(3)$ * \\
\hline \multirow{3}{*}{20 hari } & Kontrol & - & $0(5)$ \\
\hline & \multirow{2}{*}{$\begin{array}{l}\text { Perlakuan } \\
\text { 2-ME }\end{array}$} & 15 & $50(4)$ \\
\hline & & 17 & $100(4)$ * \\
\hline
\end{tabular}

UK = umur kebuntingan

* = signifikan pada $\alpha \leq 0,05$ (Mann-Whitney $\mathrm{U}$ test)

\section{PEMBAHASAN}

Kelainan perkembangan otak berupa penipisan korteks cerebrum dan atau pelebaran ventrikel lateral telah diamati pada kelompok perlakuan baik pada kelompok UK 7 maupun 13 hari. Pengamatan pada kelainan perkembangan otak ini ditujukan untuk mengetahui efek 2-ME pada jenis kelainan mikrosefalus (otak mengecil) yang ditandai dengan penipisan dari korteks cerebrum tanpa diikuti pelebaran ventrikel lateral; kelainan hidrosefalus ditandai dengan 
pembesaran ventrikel lateral. Pada kelainan hidrosefalus selain ditandai dengan pelebaran ventrikel juga diikuti pembesaran kepala (dome-shaped) akibat penekanan timbunan cairan otak (cerebrospinal fluid) yang berlebih di dalam ventrikel (Aolad et al., 2000). Bentuk kelainan hidrosefalus lainnya adalah penimbunan cairan otak di antara otak dan duramater (hidrosefalus eksternus) (Moore, 1974). Pada penelitian ini hidrosefalus yang terjadi adalah hidrosefalus internus pada bagian ventrikel cerebrum. Penelitian sebelumnya dengan menggunakan derivat 2-ME yaitu MAA yang diberikan pada mencit $\mathrm{A} / \mathrm{J}$ juga telah diketahui menyebabkan kelainan hidrosefalus (Darmanto et al., 1994a), Kelainan hidrosefalus umumnya disebabkan oleh penyumbatan aquaeductus sylvii, sehingga akan menghalangi cairan otak dalam ventrikel lateral dan ventrikel III mengalir ke ventrikel IV atau subarachnoidea (Takeuchi and Takeuchi, 1986). Namun pada penelitian kami sebelumnya dengan menggunakan mencit Slc-ICR yang diradiasi dengan sinar X pada UK 7.5 hari, hidrosefalus yang terjadi lebih disebabkan oleh penurunan kemampuan sel untuk berproliferasi di bagian ependymal pada saat perkembangan otak dan akibat gangguan perkembangan choroid plexus pada ventrikel (Aolad et al., 2000a). Choroid plexus merupakan jaringan yang terdapat dalam ventrikel yang berperan dalam mengatur proses sekresi dan resorpsi cerebrospinal fluid (cairan otak) (Aolad et al., 2000a).

Mikrosefalus (kepala yang kecil abnormal) pada penelitian ini dideteksi melalui tanda adanya penipisan korteks cerebrum tanpa diikuti pelebaran ventrikel. Kondisi mikrosefali ini ada kemungkinan disebabkan oleh adanya hambatan proliferasi dan migrasi sel neuron di bagian cerebrum sehingga menyebabkan jumlah sel neuron lebih rendah dari kontrol. Penelitian sebelumnya mendemonstrasikan tentang mekanisme terjadinya mikrosefalus yang diakibatkan oleh radiasi sinar-X, yaitu radiasi sinar-X menyebabkan ectopic gray matter, dan ditandai dengan ketidaknormalan dari radial glial cell yang berfungsi sebagai pemandu migrasi sel neuron (Sun et al., 1996; Sun et al., 1997). Dari hasil penelitian ini muncul masalah yang sangat perlu untuk dijawab yaitu apakah mikrosefalus yang mungkin terjadi akibat 2-ME ini juga berkaitan dengan ectopic gray matter sebagai akibat gangguan migrasi sel? Sehingga perlu penelitian lebih lanjut yaitu dengan pengamatan dengan menggunakan immunohistokimia.

Kelainan perkembangan pada korteks cereberum berupa kerusakan jaringan korteks, diduga disebabkan efek akut akibat induksi 2-ME, senyawa ini mampu menyebabkan kematian sel neuron di bagian korteks sebelah luar sehingga dalam perjalanan perkembangan otak, pemulihan dari proses kematian sel atau kerusakan jaringan tersebut tidak sempurna. Hal ini sesuai dengan hasil pada penelitian berupa kerusakan jaringan korteks muncul setelah anak tikus umur 10 hari dan 20 hari. Pertanyaan yang muncul adalah kenapa kerusakan tersebut cenderung terjadi pada daerah luar. Hal ini diduga, 2-ME atau metabolitnya masuk dalam sirkulasi darah, atau cairan otak terutama terjadi melalui selaput otak. Kelainan selaput otak diduga disebabkan oleh 2-ME dan metabolitnya yang masuk selaput otak dan selanjutnya masuk pada jaringan korteks yang menempel langsung pada selaput otak. Adapun tingkat kerusakan pada bagian korteks tersebut apakah sampai pada tingkat kelainan yang disebut "gliosis", masih perlu diamati dengan imunohistokimia terhadap sel glial astrosit. Pada umumnya kerusakan jaringan otak atau kematian sel neuron akan menyebabkan perangsangan terhadap sel astrosit sehingga mengalami proliferasi dan menggantikan daerah yang rusak. Proses ini disebut dengan gliosis atau penggantian sel neuron dengan sel glial astrosit (Gondona et al., 1996). Jenis kerusakan korteks ini juga telah dilaporkan sebelumnya pada tikus akibat pemberian methylmercury (Inouye, 1991).

Kelainan pada cerebellum yang muncul, sebagai akibat pemberian 2-ME pada masa akhir kebuntingan yaitu UK 15 dan 17 hari adalah berupa kelainan pola foliasi. Perkembangan cerebellum khususnya pola foliasi dimulai dari akhir masa kebuntingan yaitu sekitar UK 17 dan 18 hari, namun sel-sel penyusun cerebellum mulai muncul pada UK 15 hari ( Darmanto et al., 1998).

Dalam proses perkembangan cerebellum melibatkan proliferasi dan migrasi sel, khususnya sel Purkinje yang berasal dari daerah deep cerebellar menuju ke daerah cortical (korteks) dan sel granulosa dari daerah korteks menuju daerah intermediate zone (Darmanto et al., 1998). Hambatan terhadap proses proliferasi sudah banyak diketahui menyebabkan kelainan perkembangan, begitu juga hambatan terhadap proses migrasi sel, khususnya migrasi sel Purkinje telah terbukti menyebabkan kelainan pola foliasi pada tikus (Darmanto et al., 2000; Darmanto et al., 1998). Pada penelitian ini 2-ME telah terbukti mengganggu pola foliasi, namun pengamatan terhadap proses terjadinya penyimpangan pola foliasi masih perlu penelitian lebih lanjut. Diduga penyimpangan pola folisasi ini berkaitan erat dengan gangguan migrasi sel Purkinje, seperti pada kelainan pola foliasi akibat radiasi sinar-X. Kelainan migrasi sel Purkinje tersebut juga telah ditunjukkan secara jelas sebagai akibat menurunnya ekspresi protein ekstrasellular yaitu protein Reelin (Darmanto et al., 2000).

Dari hasil penelitian dapat disimpulkan bahwa pemberian 2-ME pada masa kritis organogenesis otak baik 
masa awal pembentukan neural tube (UK 7) maupun UK 13 yaitu masa pertumbuhan cerebrum, mampu menyebabkan penyimpangan perkembangan cerebrum berupa penipisan korteks cerebrum dan pelebaran ventrikel lateral. Sedangkan 2-ME yang diberikan pada masa pembentukan cerebellum dan perkembangan lanjut cerebrum maupun cerebellum, mampu menginduksi munculnya kelainan dan kerusakan jaringan korteks cerebrum dan penyimpangan pola foliasi cerebellum. Sehingga perlunya sosialisasi terhadap penggunaan bahanbahan plastik yang kemungkinan dapat masuk ke dalam tubuh manusia dapat menyebabkan kerusakan jaringan otak dan perlunya penelitian patogenesis terhadap kelainan otak yang terjadi.

\section{KEPUSTAKAAN}

Aolad MD, Inouye M, Hayasaka S, Takagishi Y, Darmanto W, and Murata Y., 2000. Hydrocephalus in mice following $\mathrm{X}$-irradiation at early gestational stage: Possibly due to persistent deceleration of cell proliferation. Journal of Radiation Research 41: 213-26.

Brown NA, Holt D, and Webb M, 1984. The teratogenecity of methoxyacetic acid in the rat. Toxicology Letter 22: 93-100.

Colborn T, Vom SF, and Soto AM, 1993. Developmental effects of chemicalsw in wildlife and humans. Environment Health Perspect 101: 378-84.

Darmanto W, Inouye M, Hayasaka S, Takagishi Y, Aolad H.M, and Murata Y, 1998. Dose response relationship of disturbed migration of Purkinje cells in the cerebellum due to X-irradiation. Environmental Medicine 42: 46-50.

Darmanto W, Sudarwati S, and Sutasurya LA, 1994a. Effects of methoxyacetic acid on prenatal development of mice. Environmental Medicine 38: 25-8.

Darmanto W, Kabir N, Inouye M, Takagishi Y, and Yamamura H, 1994b. Effects of 2-methoxyethanol and methoxyacetic acid on preimplantation mouse embryos in vivo. Environmental Medicine 38: 29-32.

Darmanto W, Kabir N, Inouye M, Takagishi Y, and Yamamura H, 1994c. Effects of 2-methoxyethanol and methoxyacetic acid on preimplantation mouse embryos in vitro. Environmental Medicine 38: 33-36.
Darmanto W, 1998. Efek 2-methoxyethanol terhadap pembentukan somite dan kelainan rangka aksial pada mencit. Proceeding Temu Ilmiah PPI Jepang. Hiroshima, Japan.

Feuston MH, Kerstetter SL, and Wilson PD, 1990. Teratogenicity of 2-methoxyethanol applied as a single dermal dose to rats. Fundamental Applied of Toxicology 15: 448-56.

Gondona JM, Martin MP, Cifuentes M, et al., 1996. Ependymal denudation, aqueductal obliteration and hydrocephalus after a single injection of neurominidase into the lateral ventricle of adult rats. Journal of Neuropathology and Experimental Neurology 55: 999-1008.

Hutchison JB, 1997. Gender-specific steroid metabolism in neuro differentiation. Cell Molecular and Neurobiology 17: 603-25.

Inouye M, 1991. Experimental approaches to developmental toxicity of methylmercury. Advance Mercury Toxicology. P: $339-54$.

Ketti KT, Donald BS, Stedman BB, and Welch F, 1996. Effects of 2-Methoxyethanol on Mouse Neurolation. Teratology 54: 219-29.

Moore KL, 1974. The Developing Human Clinically Oriented Embryology, 2nd ed. Sounders Co. 325-34.

Moslen MT, Kaphalia L, Balasubramanian H, Yin YM, and Au WW, 1995. Species differences in testicular and hepatic biotransformation of 2-methoxyethanol. Toxicology 96 : 217-24.

Sun XZ, Inouye M, Takagishi Y, Hayasaka S, and Yamamura H, 1996. Follow-up study on histogenesis of microcephaly associated with ectopic gray matter induced by prenatal girradiation in the mouse. Journal of Neuropathology and Experimental Neurology 55 (3): 357-65.

Sun XZ, Inouye M, Takagishi Y, Fukui Y, Hisano S, Sawada K, Muramatsu H, and Muramatsu T, 1997. An Immunohistochemical study of radial glial cells in the mouse brain prenatally exposed to g-irradiation. Journal of Neuropathology and Experimental Neurology 56 (12): 1339-48.

Takeuchi IK. and Takeuchi YK., 1986. Congenital hydrocephalus following $\mathrm{X}$-irradiation of pregnant rats on an early gestational day. Neurobehaviour, Toxicology and Teratology 8: 143-50.

Yonemoto J, and Brown NA, 1984. Effects of dimethoxyethyl phthalate, monomethyl phthalate, 2-methoxyethanol dan methoxyacetic acid on post implantation rat embryos in culture. Toxicology Letter 21: 97-102.

Reviewer: Prof. Dr. Sutiman B. Sumitro 